\title{
Hönnun starfa og starfsánægja í sérfræðistörfum hjúkrunarfræðinga, verkfræðinga og stjórnenda.
}

\author{
Arney Einarsdóttir, Sigrún Gunnarsdóttir, Ingi Rúnar Eðvarðsson, \\ Ásta Dís Óladóttir, Inga Minelgaite og Svala Guðmundsdóttir ${ }^{1}$
}

\begin{abstract}
Ágrip
Markmið greinarinnar er að greina áhrif hönnunarpátta og einkenna sérfræðistarfa á starfsánægju meðal hjúkrunarfræðinga, verkfræðinga og stjórnenda hér á landi og gera samanburð á pví hvað einkennir störf pessara priggja sérfræðistétta. Niðurstöður byggja á gögnum sem safnað var árið 2018 meðal einstaklinga í premur ofangreindum sérfræðistörfum og er heildarfjöldi svarenda 342 og svarhlutfallið $32 \%$. Hönnun starfa var mæld í fjórum víddum. Pær eru einkenni verkefna, einkenni pekkingar, félagsleg einkenni og samhengi starfs og alls 21 undirpætti. Niðurstöður sýna jákvætt samband milli starfshönnunar og starfsánægju, par sem tengsl milli einkenna verkefna og starfsánægju voru sterkust og skýra undirpættir starfshönnunarlíkansins 35\% af dreifni í starfsánægju. Ekki greinist munur á almennri starfsánægju pessara priggja sérfræðihópa en munur greinist á mati stjórnenda og hjúkrunarfræðinga á einkennum verkefna og meta stjórnendur pau hærra en hjúkrunarfræðingar. Verkfræðingar og stjórnendur meta jafnframt félagsleg einkenni starfs síns og samhengi starfsins hærra en hjúkrunarfræðingar á meðan hjúkrunarfræðingar meta einkenni pekkingar hærra en verkfræðingar. Peir undirpættir sem hafa mest áhrif á starfsánægju ofangreindra sérfræðinga eru fjölbreytni verkefna, endurgjöf frá öðrum, sjálfstæð ákvarðanataka, vinnuaðstæður og mikilvægi starfs. Niðurstöður benda til pess að svigrúm sé til staðar til pess að bæta endurgjöf frá öðrum fyrir alla sérfræðihópana prjá. Pá megi bæta vinnuaðstæður og sjálfstæði í ákvörðunartöku hjá hjúkrunarfræðingum og skapa sterkari upplifun á mikilvægi starfsins meðal verkfræðinga og stjórnenda.
\end{abstract}

\begin{abstract}
The aim of the article is to present the results of a research on job design and job satisfaction among nurses, engineers and managers in Iceland. The results are based on data collected among individuals in the above-mentioned expert jobs in 2018, and the total number of respondents is 342, with response rate of $32 \%$. Job design was measured in four dimensions - task characteristics, knowledge characteristics, social characteristics and contextual characteristics and a total of
\end{abstract}

1 Arney Einarsdóttir er lektor við viðskiptafræðideild Háskóla Íslands. Netfang: arney@hi.is. Sigrún Gunnarsdóttir er dósent við Viðskiptafræðideild Háskóla Íslands og Viðskiptafræðideild Háskólans á Bifröst. Netfang: sigrungu@hi.is. Ingi Rúnar Eðvarðsson er prófessor við viðskiptafræðideild Háskóla Íslands. Netfang: ingire@hi.is. Ásta Dís Óladóttir er lektor við Viðskiptafræðideild Háskóla Íslands. Netfang: astadis@hi.is. Inga Minelgaite er dósent við Viðskiptafræðideild Háskóla Íslands. Netfang: inm@hi.is. Svala Guðmundsdóttir er dósent við Viðskiptafræðideild Háskóla Íslands. Netfang: svala@hi.is.

This work is licensed under a Creative Commons Attribution 4.0 License.

DOI: https://doi.org/10.24122/tve.a.2019.16.1.7 
21 sub-components. The results show a positive correlation between job design and job satisfaction, where the relationship between task characteristics dimension and job satisfaction was strongest and job design explained $35 \%$ of variance in job satisfaction. A difference between the general job satisfaction of these three groups of specialists is not identified in data analysis, but differences are, however, detected in the assessment of managers and nurses on the task characteristics with managers evaluating it higher than nurses. Engineers and managers also assessed the social characteristics of their work and the context of their work higher than nurses, while nurses identified the characteristics of knowledge higher than engineers. The key factors that have the greatest impact on the job satisfaction of the above-mentioned specialists are the variety of projects, feedback from others, independent decisionmaking, working conditions and the importance of work. The results indicate improvements could be made by providing more feedback to all three specialist groups, but also by improving working conditions and independence in decisionmaking by nurses and by creating a stronger perception of job significance among engineers and managers.

JEL flokkun: M12; O15

Lykilorð: Hönnun starfa; starfsánægja; hjúkrunarfræðingar, verkfræðingar, stjórnendur.

Keywords: Job design; job satisfaction; nurses, managers, engineers.

\section{Job Design and Job Satisfaction of Specialists - Nurses, Managers and Engineers.}

\section{Inngangur}

Sífellt koma fleiri vísbendingar fram erlendis frá um aukið álag og aukna vanlíðan í starfi (International Labour Organization, 2016). Rannsóknir gefa sterkar vísbendingar um pá pætti er líklegir eru til að hafa áhrif og er hönnun starfa (e. job design) einn peirra grundvallarpátta er tengjast starfsánægju fólks og starfshæfni (Humphrey, Nahrgang, \& Morgeson, 2007). Hönnun starfa felur í sér að skipuleggja og raða saman athöfnum, verkefnum, skyldum og ábyrgð. Pá felur hönnun starfa í sér að tilgreina tæki og vinnuaðstæður sem nauðsynlegar eru fyrir tiltekið starf, ásamt pví að tilgreina félagsleg einkenni og tengsl starfa við önnur störf (Morgeson \& Humphrey, 2008). Lengi hefur verið litið á starfshönnun sem einn af hornsteinum mannauðsstjórnunar og sem einn lykilundanfara starfslýsinga og frammistöðumats.

Fræðileg umræða og rannsóknir á starfshönnun hafa próast frá peirri áherslu sem var á störf í fjöldaframleiðslufyrirtækjum, yfir í rannsóknir á pjónustu- og pekkingarstörf, eða störf sérfræðinga. Đó fjöldi erlendra rannsókna á starfshönnun liggi fyrir pá bendir margt til pess að umræðan og mælitækin sem hafi verið notuð fangi ekki nægilega vel flókin og margpætt sérfræðistörf dagsins í dag. Pá hefur verið bent á að pau endurspegli ekki sampætta hugmyndafræði og kenningar sem eiga uppruna sinn í ólíkum fræðasviðum, s.s. eins og vinnusálfræði, vinnuvistfræði og iðnaðarverkfræði (Campion \& Thayer, 1985). Til að bregðast við pessu og víkka enn frekar út sjónarhornið og til að fanga megi samtímis hvatningartengda, félagslega- og samhengistengda pætti í ólíkum og fjölbreyttum störfum, próuðu og prófuðu Morgeson og Humphrey (2006) mælitæki sem er ætlað að bæta úr pví. Pví er ætlað að fanga betur fyrirbærið starfshönnun í ólíkum störfum. Pessi rannsókn er hluti af alpjóðlegu rannsóknarverkefni (Global Work Design) um 40 landa, par sem gagna var aflað með samræmdum hætti í pátttökulöndunum á um tveggja ára tímabili, frá 2016-2018 meðal hjúkrunarfræðinga, verkfræðinga og stjórnenda. Pessir hópar voru 
valdir vegna pess að allir prír hóparnir gegna störfum sem kalla á mikla sérfræðipekkingu og fela í sér mikla ábyrgð. Verkfræðingar og hjúkrunarfræðingar eru dæmi um fjölmennar stéttir sérfræðinga sem starfa á mismunandi vettvangi og stjórnendur voru valdir af félagalista Stjórnvísis til fá innsýn í hönnun starfa hjá hópi sérfræðinga sem starfar á fjölbreyttum vettvangi par sem sérfræðipekking og ábyrgð er mjög mikil. Áhugavert er að varpa ljósi á hönnun starfa pessara priggja hópa með hliðsjón af sameiginlegum páttum sérfræðistarfa sem og páttum sem tengjast mismunandi starfsvettvangi og ábyrgð. Mælitækið sem hér er notað byggir á spurningalista um hönnun starfa (e. The work design questionnaire - WDQ).

Раð liggja ekki margar samanburðarrannsóknir fyrir um hönnun starfa í sérfræðistörfum og áhrifum einstakra pátta pess á starfsánægju hér á landi. Nokkrar rannsóknir eru til um störf hjúkrunarfræðinga, pá hefur viðhorf starfsfólks í einkageiranum og hinum opinbera verið borið saman. Minna fer fyrir rannsóknum á störfum annarra fagstétta sérstaklega, eins og verkfræðinga og stjórnenda. Mikilvægt er að auka pekkingu á pessu sviði og varpa ljósi á pað hvaða pættir starfshönnunar hafi áhrif á starfsánægju í sérfræðistörfum og að bera saman hvað einkennir störf í ólíkum sérfræðigreinum.

Markmið greinarinnar er, að skoða hvort hönnun starfa hafi áhrif á starfsánægju sérfræðinga og pá hvaða pættir hafi par mest áhrif. Pá verður gerður samanburður á pví hvað einkennir verkefni, pekkingu, félagslega pætti og samhengi starfa meðal hjúkrunarfræðinga, verkfræðinga og stjórnenda hér á landi. Pær rannsóknarspurningar sem hér eru til grundvallar eru tvær. Annars vegar hvort hönnun starfa spái fyrir um starfsánægju í sérfræðistörfum og hvaða pættir hafi par mest áhrif. Seinni rannsóknarspurningin snýr að pví hvernig sérfræðingar í pessum premur sérfræðistörfum meta starfsánægju sína og einstaka hönnunarpætti sinna starfa.

\section{Fræðilegur bakgrunnur}

\subsection{Starfshönnun og starfsánægja}

Tvípátta kenning Herzberg (1968) varpar ljósi á mikilvæga áhrifapætti starfsánægju sem eru annars vegar innri hvatar sem tengjast starfinu sjálfu og geta leitt til starfsánægju og hins vegar ytri hvatar sem varða starfsskilyrði, stöðu og laun. Séu pessir ytri hvatar ekki til staðar eru peir taldir geta leitt til óánægju í starfi, en ekki til starfsánægju. Á áttunda áratugnum birtu Hackman og Oldham rannsóknir sem beindust að fimm hvatatengdum páttum starfa sem tengjast starfsánægju, p.e. færni, einkenni verkefna, mikilvægi verkefnis, sjálfstæði og endurgjöf (Hackman \& Oldham, 1975). Stuttu síðar setti Karasek (1979) fram líkan um kröfur og sjálfstæði í starfi og áhrif stuðnings í pví sambandi (e. demand-control-support) sem leiddu af sér mikilvæga pekkingu um tengsl pessara pátta við starfsánægju og vellíðan í starfi (Karasek, Trinatis, \& Chaudry, 1982). Líkan Karasek hefur verið grunnur fjölmargra rannsókna er tengjast starfsánægju og vellíðan í starfi. Par má nefna viðamikla rannsókn Whitehall um líðan opinberra starfsmanna í Bretlandi sem hefur skapað sterkan pekkingargrunn um mikilvæga pætti í starfshönnun er tengjast vellíðan í vinnu og starfsánægju (Sjá t.d. Marmot et al., 1991; Stansfeld, Fuhrer, Shipley, \& Marmot, 1999). Sá pekkingargrunnur hefur einnig verið styrktur með frekari kenningum og rannsóknum til dæmis um gildi réttlátrar umbunar, til að mynda í formi launa, stöðu og virðingar, í pví samhengi (Kinman, 2016; Pellerin \& Cloutier, 2018; Siegerist, 1996). Í safngreiningu (e. meta-analysis) Humphrey, Nahrgang og Morgeson (2007) um rannsóknir á sviði starfshönnunar, sem náði yfir 259 rannsóknir um starfshönnun með 219.625 pátttakendum, kemur meðal annars fram að hvatatengdir pættir (e. motivational characteristics) hafa verið mest rannsakaðir. Höfundar settu fram yfirgripsmikið mælitæki á grunni pessarar safngreiningar par sem peir skiptu hvatatengdum páttum í eftirfarandi prjá meginflokka: einkenni verkefna (e. task characteristics), einkenni pekkingar (e. know- 
ledge characteristics) og félagsleg einkenni (e. social characteristics) og sýndu fram á forspá verkefna- og pekkingareinkenna og félagslegs stuðnings um starfsánægju (Morgeson og Humphrey, 2006).

Einkenni verkefna taka til fjölda og eðli peirra verkefna sem felast í starfinu, samkvæmt skilgreiningu Morgeson og Humphrey (2006) í mælitækinu sem hér er notað. •að var próað og prófað í peim tilgangi að sampætta ólík sjónarhorn og áherslur á sviði starfshönnunar. Pá taka pau einnig til pess hvernig pau eru innt af hendi og til pátta eins og sjálfstæðis, fjölbreytni verkefna og mikilvægi starfs. Einkenni pekkingar vísar til peirrar pekkingar og færni sem starfið krefst og tekur til pátta eins og úrvinnslu upplýsinga, lausn vandamála og sérhæfingar. Félagsleg einkenni taka til pátta eins og félagslegs stuðnings á vinnustað, frumkvæðis og mikilvægi samvinnu, samskipta við aðila utan fyrirtækis eða stofnunar og endurgjafar frá öðrum. Samhengi starfs (e. contextual characteristics) vísar til pátta er tengjast vinnuvistfræði (e. ergonomics) eins og almennra vinnuaðstæðna, notkunar tækja og líkamlegrar áreynslu í starfi. Safngreining Hymphrey og félaga (2007) leiddi í ljós að pættir tengdir hönnun starfa hafa mikil áhrif á viðhorf starfsmanna og hegðun peirra og skýrðu peir pættir $43 \%$ af breytileika í ýmsum starfstengdum viðhorfum og hegðun pátttakenda. Sjálfstæði í starfi og félagslegur stuðningur reyndust spá best fyrir um starfsánægju par sem pessir hvatatengdu pættir í hönnun starfa skýrðu 34\% af dreifni í starfsánægju, á meðan félagslegir pættir skýrðu 17\% og samhengi starfs, eða ýmsir aðstæðubundnir pættir skýrðu $4 \%$.

Í viðamikilli evrópskri rannsókn sem náđi til tæplega 37 púsund pátttakenda úr ólíkum starfsstéttum pá voru tilgangur starfsins (e. work meaningfulness), geta til að taka ákvarðanir og félagslegur stuðningur afar mikilvægir pættir pegar kom að hönnun starfa (Lorente, Tordera, \& Peiró, 2018). Tilgangur starfsins og starfsánægja miðluðu sambandinu á milli starfsumhverfis og sálfræðilegrar velferðar starfsmanna. Getan til að taka ákvarðanir og félagslegur stuðningur höfðu marktæk jákvæð tengsl við starfsánægju og tilgang starfsins á meðan tímapressa hafði neikvæð tengsl við starfsánægju og tilgang starfsins. Svipaðar niðurstöður komu fram í kerfisbundinni samantekt á rannsóknum á starfsánægju hjúkrunarfræðinga. Hún leiddi í ljós marktæk jákvæð tengsl á milli stuðnings yfirmanna, sjálfstæðis í starfi og pess að finnast starfið skipta máli, við starfsánægju (Han, Carter, \& Champion, 2018). Erlendar rannsóknir hafa sýnt að kyn, aldur og menntun hafi áhrif á starfsánægju, p.e.a.s. að konur séu ánægðari en karlar, aldurstengslin séu U-laga og að menntun hafi neikvæð áhrif (Clark, 1997; Clark, Oswald, \& Warr, 1996; Sousa-Poza \& Sousa-Poza, 2000). Pá má greina menningarlegan breytileika milli landa og eftir starfsstéttum (Sousa-Poza \& Sousa-Poza, 2000). Til marks um pann menningarlega breytileika pá greindist hvorki kynbundinn né menntunarlegur munur í rannsókn sem framkvæmd var meðal 2440 starfsmanna í fjölbreytilegum störfum í 36 fyrirtækjum hér á landi. Pá voru tengsl aldurs við starfsánægju línulega jákvæð með hækkandi aldri (Arney Einarsdóttir \& Sigríður P. Stefánsdóttir, 2008).

pættir sem tengjast tilgangi starfa, skipulagi og stjórnun komu einnig fram í niðurstöðu safngreiningar á 99 rannsóknum um starfsánægju opinberra starfsmanna par sem sterkustu marktæku tengslin við starfsánægju komu fram gagnvart tilgangi starfa, hollustu, að starfið félli að viðkomandi einstaklingi, pátttöku, trausti, innri starfshvöt, réttlæti, sjálfstæði, skýrleika, árangri skipulagsheildar og hversu vel skipulagsheild og einstaklingur eiga saman (Cantarelli, Belardinelli, \& Belle, 2016). Tvær viðamiklar safngreiningar um starfsánægju í tengslum við valdeflandi pætti í starfsumhverfinu leiddu í ljós sterk marktæk tengsl undirpátta valdeflingar á vinnustað við starfsánægju í almennum hópi starfsmanna ( $\mathrm{n}=6.207)$ (Seibert, Wang, \& Courtright, 2011). Hið sama á við um störf hjúkrunarfræðinga miðað við 1572 rannsóknir par um (Li o.fl., 2018) og einnig um rannsókn í Pýskalandi sem byggir á svörum frá 3545 einstaklingum (Fahr, 2011). Valdeflandi pættir á vinnustað í ofangreindum rannsóknum ná pví til hönnunar starfa og pátta sem tengjast félagslegum stuðningi á vinnustað, tækifærum til starfspróunar, tilgangi starfa, hæfni, sjálfstæði og áhrifa á eigin störf. 


\subsection{Rannsóknir hér á landi og sérfræðistörf}

Hér á landi hefur tiltölulega lítið farið fyrir umræðu og rannsóknum sem beinast beint að hönnun starfa, en áherslan verið peim mun meiri á starfsánægju og tengda pætti. Af peim rannsóknum má pó draga einhverjar ályktanir varðandi hönnun starfa. Rannsóknir á starfsánægju opinberra starfsmanna sýna marktæk tengsl starfsánægju við virðingu, sjálfstæði, ábyrgð og fagmennsku (Guðmundur Ingi Guðmundsson \& Guðbjörg Linda Rafnsdóttir, 2010), tækifæri til að proskast í starfi, starfið sé metið að verðleikum, góðan starfsanda og vinnuaðstöðu (Ómar Kristmundsson, 2007). Einnig hafa rannsóknir hér á landi sýnt fram á að stuðningur stjórnenda, tækifæri til pess að vaxa í starfi, ábyrgðarskylda og að hafa áhrif á eigin störf (Guðjón Ingi Guðjónsson \& Sigrún Gunnarsdóttir, 2014; Sigrún Gunnarsdóttir \& Sandra Borg Gunnarsdóttir, 2018) skipti máli ásamt góðri stjórnun, umhyggju stjórnenda fyrir líðan starfsmanna, vinnuálag og starfsöryggi (Hjördís Sigursteins-dóttir, 2016). Í rannsókn á starfsánægju hér á landi meðal starfsfólks á almennum markaði og í opinberum stofnunum kom fram að mikilvægustu áhrifapættir starfsánægju eru starfið og inntak pess og starfsskilyrði (Arney Einarsdóttir, 2007). Рað fyrra tekur á inntaki starfa og eðli peirra en pað síðara á vinnuaðstæðum og vinnuálagi.

Pá hafa rannsóknir hér á landi sýnt að ýmsir aðrir pættir eins og stuðningur næsta yfirmanns, tækifæri til að proskast í starfi, jákvæð samskipti við samstarfsfólk og hæfilegt álag tengjast marktækt minni líkum á einkennum kulnunar meðal hjúkrunarfræðinga (Sigrún Gunnarsdóttir ofl., 2009) og meiri líkum á starfsánægju peirra (Gunnarsdóttir, Clarke, Rafferty \& Nutbeam, 2009; Hulda Rafnsdóttir, Ragnheiður Harpa Arnarsdóttir, \& Sigrún Gunnarsdóttir, 2015). Eigindleg rannsókn á Landspítala gaf jafnframt sterkar vísbendingar um að innri starfshvöt, p.e. innri pættir starfsins, sjálfstæði í starfi, samstarf og tilgangur starfsins væru mikilvægir pættir fyrir vellíðan og starfsánægju hjúkrunarfræðinga (Gunnarsdóttir, 2005). Svipaðar niðurstöður komu fram í eigindlegri rannsókn um starfshvatningu heilsugæsluhjúkrunarfræðinga hér á landi bar sem auk innri pátta starfsins voru tækifæri til að vaxa í starfi, samskipti við stjórnendur, hvatning og efnisleg umbun einnig mikilvægir hvatapættir (Halldórsdóttir, Einarsdóttir, \& Eðvarðsson, 2018).

Pekkt er að vinnuumhverfið í einkageiranum og hjá hinu opinbera geti verið nokkuð ólíkt á mörgum sviðum. Íslensk rannsókn sem framkvæmd var fyrir efnahagshrunið árið 2008 sýndi til að mynda jákvæðari viðhorf starfsfólks í einkageiranum heldur en í opinbera geiranum. Рað birtist í jákvæðari upplifun starfsfólks á stuðningi, sanngirni í verklagi og upplýsingastreymi og mati á árangri mannauðsstjórnunar en sýndi ekki mun á starfsánægju (Hlín Kristbergsdóttir, Leifur Geir Hafsteinsson, \& Arney Einarsdóttir, 2008). Rannsóknir sem gerðar voru strax í kjölfar hrunsins hafa ekki gefið vísbendingar um neikvæð áhrif á starfsánægju (Arney Einarsdóttir \& Ásta Bjarnadóttir, 2010). Hins vegar dró úr peim mun sem var á opinbera geiranum og einkageiranum í heildarupplifun starfsfólks á ýmsum páttum s.s. í mati á stuðningi og sanngirni. Pó benda aðrar rannsóknir til pess að pær samdráttar- og aðhaldsaðgerðir sem gripið var til hafi haft neikvæð áhrif til lengri tíma á starfsánægju starfsfólks sveitarfélaga (Hjördís Sigursteinsdóttir, 2016). Jafnframt bendir margt til pess að álag í störfum hjúkrunarfræðinga hafi aukist á síðustu árum í kjölfar hrunsins, en flótti úr peim störfum hefur vakið athygli opinberra eftirlitsaðila (Ríkisendurskoðun, 2017).

Rannsóknir um hönnun starfa sem komu fram í upphafi 20. aldarinnar, til dæmis rannsóknir Taylor og Hawthorne rannóknirnar, beindust að framleiðslustörfum með áherslu á að greina verkpætti (e. task analysis) og að auka framleiðni. Í pví samhengi er stundum talað um „Taylorisma“, sem vísar í áherslu á framleiðniaukningu með fjöldaframleiðslu og sköpun einhæfra starfa á verksmiðjugólfi. Um miðja síðustu öld fara aðrir pættir að koma sterkar inn í umræðuna er varða félagslega pætti, hvatningu og starfsánægju og fjölbreyttari störf og p.m.t. pjónustustörf. Peter Drucker (1999) varpaði ljós á að aðrir pættir hafi áhrif á hvatningu, starfsánægju og framleiðni hjá pekkingarstarfsfólki (e. knowledge workers) heldur en hjá ófaglærðu starfsfólki í verksmiðju og fólki í almennum pjónustu- 
störfum. Drucker taldi pað eina af lykiláskorunum 21. aldarinnar að leitast við að varpa ljósi á og fylgjast með pví hvað skapi hvatningu í slíkum störfum.

Drucker (1999) benti á að eftirfarandi pættir væru mikilvægir fyrir störf pekkingarstarfsmanna: 1) skýr lýsing og skilningur á pví hvað felst í verkefnum; 2) ábyrgð og sjálfstæði; 3) áhersla á stöðugar framfarir og lærdóm; 4) áhersla á gæði frekar en magn; 5) að litið sé á pekkingarstarfsmanninn sem mikilvægan auð sem hefur áhuga á að vinna í skipulagsheildinni. Niðurstöður Carleton (2011) um hvata í störfum pekkingarstarfsmanna eru í samræmi við niðurstöðu Drucker, p.e. að mikilvægir hvatar fyrir störf peirra séu tilgangur starfa, tækifæri til að læra og próast í starfi, aðgengi að bjargráðum, viðurkenning á framlagi og styðjandi starfsumhverfi. Carleton (2011) benti jafnframt á mikilvægi pekkingarstarfsmanna á upplýsingaöld og á tímum hraðra breytinga. Samkvæmt Hagstofu Íslands (2018b) hefur hlutfall sérfræðinga af heildarfjölda á vinnumarkaði nær tvöfaldast síðastliðin 20 ár á Íslandi og endurspeglar sú próun hærra menntunarstig pjóðarinnar sem og pær starfabreytingar sem átt hafa sér stað hér á landi síðastliðin 20 ár. Árið 1998 voru sérfræðingar aðeins 12\% af heildarfjölda á vinnumarkaði, árið 2008 var hlutfallið komið í 19\% og árið 2018 í 23\%. Einnig jókst hlutfall peirra sem starfa sem stjórnendur og embættismenn úr 7\% í 10\% á pessu sama tímabili. Á sama tíma lækkaði hlutfall peirra sem eru í ósérhæfðum störfum, sem og í skrifstofustörfum, úr 9\% í 5\% í báðum tilvikum.

Fyrri rannsóknir gefa vísbendingar um að pættir starfshönnunar tengist starfsánægju og meðal mikilvægra pátta eru jákvæð samskipti, félagslegur stuðningur, sjálfstæði, ábyrgð, tilgangur starfa og tækifæri til að proskast í starfi. Ljóst er að lítið sem ekkert er um samanburðarrannsóknir á hönnun starfa og starfsánægju í öðrum sérfræðistéttum en meðal hjúkrunarfræðinga hér á landi. Einnig er lítið um rannsóknir, bæði hérlendis sem erlendis, á störfum verkfræðinga og stjórnenda en mun meira um rannsóknir er lúta að störfum og starfsánægju hjúkrunarfræðinga sérstaklega. Рað gefur tilefni til að leitast við að svara tveimur rannsóknarspurningum, annars vegar hvort hönnun starfa spái fyrir um starfsánægju í sérfræðistörfum og hvaða pættir hafi par mest áhrif og hins vegar hvernig sérfræðingar í pessum premur sérfræðistörfum meta starfsánægju sína og einstaka hönnunarpætti sinna starfa.

\section{Aðferð}

Hér er gerð grein fyrir úrtaksgerð, pátttakendum, framkvæmd, mælitæki og úrvinnslu í pessari rannsókn.

\subsection{Pátttakendur og framkvæmd}

Rannsóknin er hluti af alpjóðlegu rannsóknarverkefni (Global Work Design) um 40 landa. Gagna var aflað með samræmdum hætti í pátttökulöndunum á um tveggja ára tímabili, frá 2016-2018 meðal hjúkrunarfræðinga, verkfræðinga og stjórnenda. Hér á landi var leitað til æðstu stjórnenda einstakra stofnana og fyrirtækja par sem starfa hjúkrunarfræðingar (heilbrigðisstofnanir) og verkfræðingar (hátækniframleiðslu-, mannvirkja- og orkugeirinn). Stjórnendur viðkomandi fyrirtækja eða stofnana voru beðnir um að taka 50-100 manna úrtak úr ofangreindum starfsmannahópum úr starfsmannaskrá. Í nokkrum tilvikum var úrtakið pó aðeins minna vegna fjölda starfandi í viðkomandi störfum í skipulagsheildunum. Alls tóku fimm heilbrigðisstofnanir og prjú fyrirtæki í hátækniframleiðslu, mannvirkja og/eða orkugeiranum pátt í verkefninu. Pegar kom að stjórnendum sem pátttakendum var leitað til Stjórnvísis, fagfélags um stjórnun á Íslandi og tekið 20\% slembiúrtak úr félagatali. Heildarúrtakið var alls 1060 starfsmenn, par af 201 hjúkrunarfræðingar, 137 verkfræðingar og 722 stjórnendur (sjá töflu 1).

Gagna var aflað með rafrænum könnunum meðal starfsfólks hér á landi á tímabilinu september - desember 2018. Heildarfjöldi svarenda er 342 og svarhlutfallið í heildina 32\%. Svarhlutfall meðal verkfræðinga var 55\% en lægst var pað meðal stjórnenda eða 25\% (sjá nánar töflu 1). Pátttaka starfsmanna og stjórnenda var valfrjáls. 
Tafla 1. Pátttakendur og svarhlutfall

\begin{tabular}{lccc}
\hline Fagstéttir & Úrtak & Svarendur & Svarhlutfall \\
\hline Hjúkrunarfræđingar & 201 & 82 & $41 \%$ \\
Verkfræđingar & 137 & 76 & $55 \%$ \\
Stjórnendur & $\mathbf{7 2 2}$ & 184 & $25 \%$ \\
\hline & $\mathbf{1 0 6 0}$ & $\mathbf{3 4 2}$ & $\mathbf{3 2 \%}$ \\
\hline
\end{tabular}

Konur voru 65\% svarenda. Alls voru 97\% í svarendahópi hjúkrunarfræðinga konur en hlutfall kvenna í Félagi íslenskra hjúkrunarfræðinga er samkvæmt ársskýrslu 2018-2019 pað sama (Félag íslenskra hjúkrunarfræðinga, 2019). Í hópi svarenda meðal verkfræðinga voru 20\% konur en hlutfallið samkvæmt ársskýrslu Verfræðingafélags Íslands 2018-2019 er 17,7\% (Verkfræðingafélag Íslands, 2019). Alls, voru 68\% svarenda í stjórnendahópnum konur en samkvæmt upplýsingum frá framkvæmdastjóra Stjórnvísi eru konur um 70\% félagsmanna (munnleg heimild 27. maí 2019) en samkvæmt Hagstofu Ísland (2018a) eru 23\% framkvæmdastjóra konur en engar upplýsingar eru til um hlutfallið meðal millistjórnenda. Alls voru 91\% svarenda með háskólapróf og meðalaldur svarenda var 35 ár, sá yngsti var 24 ára en elsti 78 ára. Meirihluti, eða 61\% í stjórnendahópi svarenda er með mannaforráð. Meðallengd vinnuvikunnar voru 41,6 tímar, eða allt frá 18 klukkustundum á viku til 90 klukkustunda. Meðalstarfsaldur pátttakenda var 8,15 ár. Gögnin eru ekki rekjanleg til einstaklinga og um upplýst sampykki að ræða. Tilkynning um rannsóknina var send til Persónuverndar.

\subsection{Mælitæki}

Spurningalistinn samanstóð af tveimur mælitækjum, annars vegar spurningalista um starfshönnun, The Work Design Questionnaire (WDQ) (Morgeson \& Humphrey, 2006) og hins vegar spurningum sem mæla almenna starfsánægju (e. global job satisfaction) (Campion, 1988). Við prófun á mælitæki Morgeson \& Humphrey (árið 2006) var mælitæki Campion, sem mælir almenna starfsánægju, notað. Рað er einnig notað í pessari rannsókn. Starfshönnunarmælitækið hefur verið prófað með 540 pátttakendum í 243 ólíkum störfum og sýnt fram á mjög góðan áreiðanleika og samleitnis (e. convergent) og aðgreinandi (e. discriminant) réttmæti einstakra pátta mælitækisins (Morgeson \& Humphrey, 2006). Í samræmi við ofangreinda réttmætis og áreiðanleikagreiningu samanstendur mælitækið hér af 77 spurningum. Pær mynda fjóra yfirpætti mælitækisins, p.e.a.s. einkenni verkefna, einkenni pekkingar, félagsleg einkenni og samhengi starfs. Alls eru skilgreindir 21 undirpáttur (4-7 undirpættir fyrir hvern pátt) og fyrri prófanir og páttagreining sýndu fram á bestu samsvörun (e. best fit) mælitækisins með pessum 21 pætti. Hver yfirpáttanna fjögurra er pví samsettur úr nokkrum undirhugsmíðum sem samtals mynda 21 pátt (sjá nánar töflu 2) og er hver og einn mældur með á bilinu 3 til 9 spurningum.

Tafla 2. Yfir- og undirpættir spurningalista um hönnun starfa (WDQ).

\begin{tabular}{llll}
\hline Einkenni verkefna & Einkenni pekkingar & Félagsleg einkenni & Samhengi starfs \\
\hline Sjálfstæði í skipulagi & Margbreytileiki starfs & Félagslegur stuðningur & Vinnuvistfræði \\
Sjálfstæði í ákvarđanatöku & Úrvinnsla upplýsinga & Áhrif á störf annarra & Líkamlegar kröfur \\
Sjálfstæð vinnubrögð & Úrlausn vandamála & Áhrif annarra á mín störf & Vinnuađstæđur \\
Fjölbreytni verkefna & Fjölbreytileiki færni & Samskipti utanhúss & Notkun tækja \\
Mikilvægi starfs & Sérhæfing & Endurgjöf frá öđrum & \\
Heildstæđi verkefna & & & \\
\hline
\end{tabular}

Allar spurningar voru settar fram sem staðhæfingar sem svarendur tóku afstöðu til á Likert kvarðanum 1-5, frá „Mjög ósammála“ til „Mjög sammála“. Staðhæfingar voru almennt jákvætt orðaðar pannig að pví meira sammála sem svarandi er pví betur lýsandi er viðkomandi einkenni í starfi svarandans. Undantekningarnar frá pessu eru spurningar 
í undirpáttunum margbreytileiki starfsins og eitt atriði í pættinum vinnuvistfræði og en peim atriðum var snúið fyrir úrvinnslu. Einnig var atriðum í páttunum líkamlegar kröfur og notkun tækja snúið.

Spurningalistar voru pýddir pannig að tveir rannsakenda pýddu spurningarnar úr ensku yfir á íslensku. Pá var íslenska útgáfan bakpýdd aftur á ensku af löggiltum skjalapýðanda. Bakpýðingin var send til sampykktar hjá stýrihópi alpjóðlega rannsóknarteymis (GWD) pessa verkefnis. Farið var gaumgæfilega yfir niðurstöður og rökrædd atriði par sem bakpýðing stemmdi ekki við upprunalegar spurningar á ensku og komist að sameiginlegri niðurstöðu um útfærslu.

Yfirpátturinn Einkenni verkefna í starfshönnunarmælitækinu samanstendur af 7 undirpáttum (sjá töflu 2) og 24 spurningum. Dæmi um spurningu sem mælir sjálfstæði í skipulagi er "Í starfinu get ég skipulagt hvernig ég vinn vinnu mína“ og dæmi um spurningu sem mælir heildstæði verkefna er „Starfið er skipulagt pannig að ég geti unnið heilt verkefni frá upphafi til enda“ og dæmi um spurningu sem mælir endurgjöf frá starfi er „Vinnan sjálf gefur beinar og skýrar upplýsingar um pað hve vel (t.d. um gæði og magn) ég stend mig í vinnunni." Innri áreiðanleiki (e. Cronbach Alpha) kvarðans var 0,89.

Eins og sjá má í töflu 2 samanstendur yfirpátturinn Einkenni pekkingar af alls fimm undirpáttum og eru spurningar 20 talsins. Dæmi um spurningu í undirpættinum margbreytileiki starfs er "Starfið samanstendur af frekar einföldum verkefnum" en í pessum pætti var atriðum snúið við úrvinnslu. Í pættinum úrlausn vandamála er eftirfarandi dæmi um spurningu „Í starfinu felst að leysa vandamál sem ekki hafa augljóst rétt svar“. Innri áreiðanleiki páttarins var 0,90.

Yfirpátturinn Félagsleg einkenni er settur saman úr fimm undirpáttum (sjá töflu 2) og alls 19 spurningum. Dæmi um spurningu sem tekur á félagslegum stuðningi er „Mér gefst tækifæri til að kynnast öðru fólki í vinnunni“ og dæmi um spurningu sem tekur á áhrifum á störf annarra er "Aðrir geta ekki lokið vinnu sinni nema minni vinnu sé lokið“. Innri áreiðanleiki páttarins hér var 0,78.

Pátturinn Samhengi starfs er byggður á fjórum undirpáttum (sjá töflu 2) og 14 spurningum. Spurningarnar „Sætaskipanin í vinnunni er viðunandi (t.d. næg tækifæri til að setjast, pægilegir stólar, góður stuðningur við rétta líkamsstöðu)“ og „Vinnustaðurinn er laus við mikinn hávaða" eru dæmi um spurningar sem snúa að vinnuvistfræði og vinnuaðstæðum. Dæmi um spurningar sem falla undir pættina líkamlegar kröfur, er „,starfið krefst mikils líkamlegs erfiðis“ og notkun tækja „Í starfinu felst notkun fjölda ólíkra tækja“ en spurningum sem falla undir pessa pætti var snúið pannig að pví minni líkamlegar kröfur og minni tækjanotkun pví hærra mat. Innri áreiðanleiki páttarins hér var 0,91.

Spurningar sem mæla starfsánægju voru fimm talsins og koma pær frá mælitæki Campion (1988). Dæmi um spurningu er „Á heildina litið er ég ánægð(ur) með starf mitt”. Innra samræmi og áreiðanleiki kvarðans hér var 0,90. Innri áreiðanleiki allra undirpátta mælitækisins (21 talsins) var einnig ásættanlegur, eða á bilinu frá 0,75-0,91.

\section{3 Úrvinnsla}

Meðaltöl, staðalfrávik og tengsl milli hugsmíða eru greind með Anova. Áreiðanleiki er prófaður fyrir allar yfir- og undirhugsmíðar. Framkvæmd var prepaskipt fjölbreytuaðhvarfsgreining par sem stjórnað var fyrir aldri, kyni, menntun og lengd vinnuviku til að greina nánar forspá bæði einstakra yfirpátta starfshönnunar, sem og undirpátta, um starfsánægju. Boselie, Dietz og Boon (2005) sýndu fram á að í rannsóknum par sem viðhorf og upplifun starfsfólks eru rannsökuð eru bakgrunnsbreyturnar kyn, aldur og menntun helst notaðar en ítrekað hefur verið sýnt fram á að pær hafi áhrif pó pað geti verið með mismunandi hætti í ólíku samhengi (Arney Einarsdóttir og Sigríður P. Stefánsdóttir, 2008). Einnig var stýrt fyrir lengd vinnuvikunnar hér par sem vinnuvikan er nokkuð löng á Ísland (OECD, e.d.) en einnig er nú vaxandi umræða um styttingu vinnuvikunnar hér á landi. Til að kanna hvernig sérfræðingar í pessum premur sérfræðistörfum 
meta starfsánægju sína og einstaka hönnunarpætti sinna starfa var notuð dreifigreining (Anova) og Bonferroni prófun til að leiðrétta fyrir margföldum samanburði og meðaltöl fyrir einstaka pætti meðal sérfræðigreinanna priggja pannig borin saman.

\section{Niðurstöður}

Í töflu 3 má sjá meðaltöl og fylgni milli yfirhugsmíða og við bakgrunnsbreytur. Áreiðanleikagreining yfir- og undirpátta (Cronbach alpha) kemur fram í sviga fyrir neðan númer viðkomandi páttar.

Tafla 3. Meðaltöl, dreifitölur, fylgni og áreiðanleiki pátta

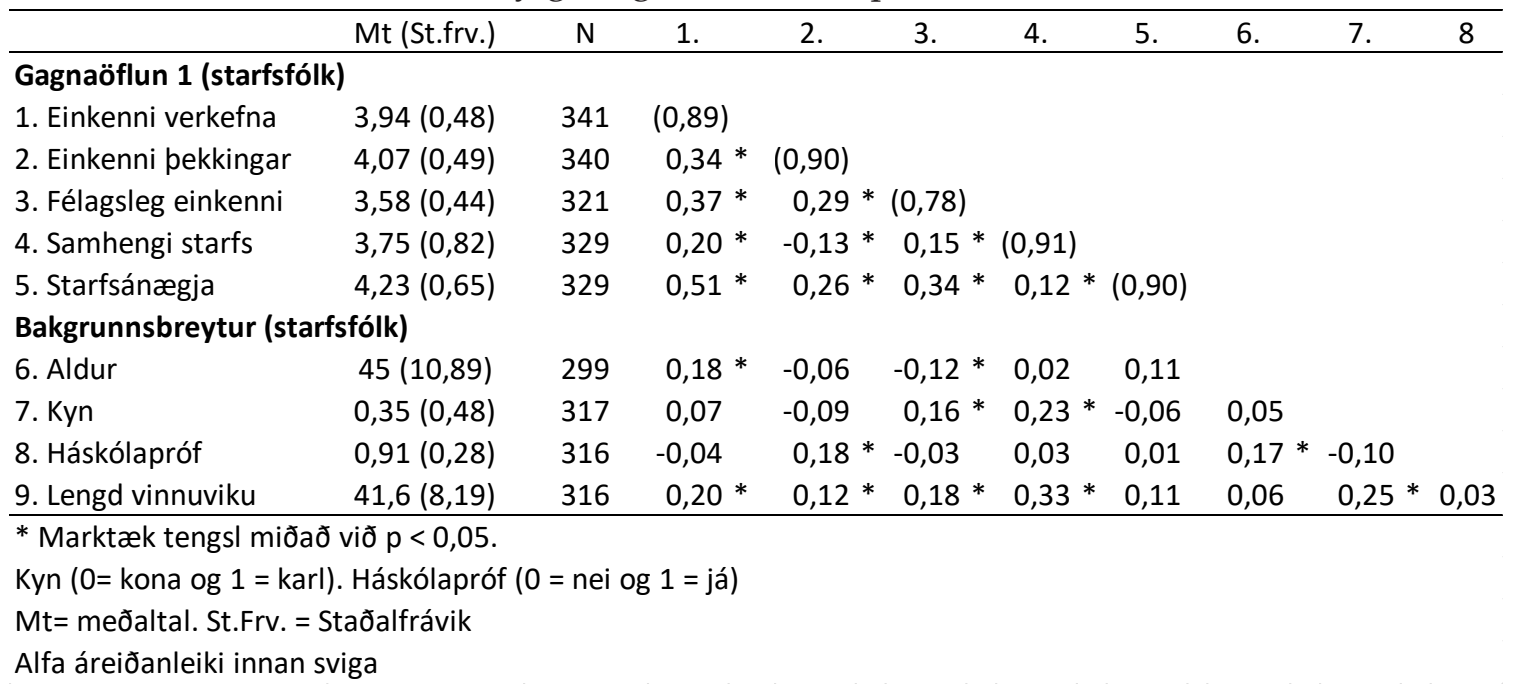

Frumniðurstöður fylgnigreiningar í töflu 3 sýna marktæk tengsl milli allra einstakra yfirpátta starfshönnunar og starfsánægju (sjá nánar fylgnigreiningu undirpátta í viðauka I). Starfsánægja meðal pessa priggja sérfræðingahópa mælist nokkuð há, eða að meðaltali 4,23 (á bilinu 1-5). Sterkust marktæk tengsl eru milli páttarins Einkenni verkefna (sjálfstæði, fjölbreytni, mikilvægi, heildstæði og endurgjöf frá starfi) við starfsánægju en lægst fylgni við Samhengi starfs. Einnig eru marktæk jákvæð tengsl milli Einkenna verkefna og bæði aldurs (eldri upplifa verkefnin sín með jákvæðari hætti en peir eldri) og lengdar vinnuvikunnar. Einkenni pekkingar (margbreytileiki starfs, úrvinnsla upplýsinga, úrlausn vandamála, fjölbreytileiki færni og sérhæfing) er með jákvæð marktæk tengsl við háskólapróf og einnig við lengd vinnuvikunnar. Einnig eru tengslin jákvæð milli Félagslegra einkenna starfa við lengd vinnuviku og kyn en neikvæð með tilliti til aldurs. Marktæk jákvæð tengsl eru milli Samhengis starfs og kyns, sem og lengdar vinnuviku (karlar meta samhengið jákvæðar og peir sem vinna langa vinnuviku meta samhengið jákvæðar en peir sem vinna styttri vinnuviku).

Karlar meta félagsleg einkenni starfs síns og lengd vinnuvikunnar marktækt hærra en konur (sjá töflu 3). Marktæk jákvæð tengsl eru milli lengdar vinnuviku og Samhengi starfs, p.e.a.s. styttri vinnuvika eftir pví sem samhengið er betra. Jákvæð marktæk tengsl eru innbyrðis milli allra starfshönnunarpátta sem hér eru mældir, nema milli einkenna pekkingar og samhengis starf, en par eru tengslin marktækt neikvæð, p.e.a.s. par sem pekking er metin hærra par er samhengið eða ýmislegt vinnutengt samhengi metið verra. Engin marktæk tengsl greinast á milli bakgrunnsbreyta, p.e.a.s. aldurs, kyns, háskólaprófs og lengdar vinnuviku, við starfsánægju.

Framkvæmd var annars vegar fjölbreytuaðhvarfsgreining fyrir yfirpætti (niðurstöður feitletraðar í töflu 4) og hins vegar undirpætti líkansins. Eins og sjá má í töflu 4 skýra bakgrunnsbreyturnar fjórar saman aðeins 3,3\% af dreifni í starfsánægju en yfirpættir starfshönnunarlíkansins skýra hins vegar um 25\% af dreifninni pegar bætt við í prepi 2 í fjö- 
breytuaðhvarfsgreiningu. Yfirpættirnir einkenni verkefna og félagsleg einkenni og hafa báđir marktæk áhrif á starfsánægju en einkenni pekkingar og samhengi starfsins hins vegar ekki. Pegar öllum undirpáttum er hins vegar bætt við í prepi 2 í aðhvarfsgreiningu skýra peir saman um 35\% af dreifninni. Pegar aðhvarfsgreining er framkvæmd með öllum undirpáttum hafa undirpættirnir fjölbreytni verkefna, endurgjöf frá öðrum, sjálfstæð ákvarðanataka, vinnuaðstæður og mikilvægi starfs allir marktæk áhrif og í pessari mikilvægisröð. Veik áhrif lengdar vinnuviku sem sjá má í líkani 1 hverfa pegar starfshönnunarpáttum er bætt inn í líkanið í prepi 2 í fjölbreytuaðhvarfsgreiningu.

Tafla 4. Fjölbreytuaðhvarfsgreiningar - forspá starfshönnunar um starfsánægju

\begin{tabular}{|c|c|c|c|c|}
\hline & \multicolumn{2}{|c|}{ Líkan 1} & \multicolumn{2}{|c|}{ Líkan 2} \\
\hline & $B$ & SE (SS) & $B$ & SE (SS) \\
\hline (Stöđugleiki/Constant) & $16,24 *$ & 6,79 & $7,82^{*}$ & 6,18 \\
\hline Aldur & $-0,01$ & 0,00 & 0,00 & 0,00 \\
\hline Kyn & $-0,12$ & 0,08 & $-0,10$ & 0,07 \\
\hline Háskólapróf & $-0,01$ & 0,13 & 0,01 & 0,11 \\
\hline Lengd vinnuviku & $0,01 *$ & 0,01 & 0,00 & 0,01 \\
\hline Einkenni verkefna & & & $0,56 *$ & 0,08 \\
\hline Sjálfstæđi í skipulagi & & & 0,06 & 0,07 \\
\hline Sjáfstæð ákvarđanataka & & & $0,15 *$ & 0,07 \\
\hline Sjálfstæð vinnubrögð & & & 0,03 & 0,07 \\
\hline Fjölbreytni verkefna & & & $0,25 *$ & 0,07 \\
\hline Mikilvægi starfs & & & $0,11 *$ & 0,05 \\
\hline Heildstæð verkefni & & & 0,03 & 0,05 \\
\hline Endurgjöf frá starfi & & & $-0,03$ & 0,05 \\
\hline Einkenni pekkingar & & & 0,08 & 0,08 \\
\hline Margbreytileiki starfs & & & 0,02 & 0,06 \\
\hline Úrvinnsla upplýsinga & & & $-0,12$ & 0,07 \\
\hline Úrlausn vandamála & & & 0,03 & 0,06 \\
\hline Fjölbreytileiki færni & & & $-0,05$ & 0,08 \\
\hline Sérhæfing & & & 0,04 & 0,05 \\
\hline Félagsleg einkenni & & & $0,24 *$ & 0,08 \\
\hline Félagslegur stuðningur & & & 0,14 & 0,08 \\
\hline Áhrif á störf annarra & & & 0,01 & 0,04 \\
\hline Áhrif annarra á mín störf & & & 0,02 & 0,05 \\
\hline Samskipti utanhúss & & & 0,00 & 0,04 \\
\hline Endurgjöf frá öđrum & & & $0,17 *$ & 0,04 \\
\hline Samhengi starfs & & & 0,04 & 0,04 \\
\hline Vinnuvistfræði & & & 0,05 & 0,05 \\
\hline Líkamlegar kröfur & & & $-0,05$ & 0,05 \\
\hline Vinnuađstæður & & & $0,12 *$ & 0,05 \\
\hline Notkun tækja & & & $-0,03$ & 0,03 \\
\hline Stýrð dreifing & \multicolumn{2}{|c|}{ Líkan 1} & \multicolumn{2}{|c|}{ Líkan 2} \\
\hline $\mathrm{R} 2$ & 0,033 & 0,04 & 0,286 & 0,391 \\
\hline Adjusted R2 & 0,020 & 0,02 & 0,265 & 0,333 \\
\hline R2 change/breyting & 0,033 & 0,04 & 0,253 & 0,355 \\
\hline F fyrir breytingu á R2 & 2,461 & 2,63 & 25,095 & 7,380 \\
\hline
\end{tabular}

SE (SS) = Standard error (Staðalskekkja)

Í prepi 1 í líkani 1 voru bakgrunnsbreytur settar inn í jöfnuna en

yfirpáttum/undirpáttum bætt inn í prepi 2 í líkani 2 -

$\mathrm{N}=284-293$. Háskólapróf = 0 án háskólaprófs og 1 međ háskólapróf

Allar feitletrađar niðurstöđur vísa til ađhvarfsgreiningar með yfirpætti 
Eins og áđur kom fram, til að draga úr líkum á að munur mælist marktækur fyrir tilviljun í Anova greiningu voru Bonferroni leiðréttingarprófanir notaðar við samanburð á meðaltölum einstakra pátta milli sérfræðigreinanna priggja. Eins og sjá má í töflu 5 er ekki marktækur munur á starfsánægju pessara priggja starfsstétta en á hinn bóginn má greina marktækan mun á starfshönnunarpáttunum fjórum. Marktækur munur greinist á mati stjórnenda og hjúkrunarfræðinga á einkennum verkefna $(p=, 006)$ og meta stjórnendur pau hærra en hjúkrunarfræðingar. Hjúkrunarfræðingar meta pó einkenni pekkingar marktækt hærra en verkfræðingar ( $p=0,027)$. Verkfræðingar og stjórnendur meta jafnframt félagsleg einkenni starfs síns marktækt hærra $(p=0,041$ og $p=0,029)$ en hjúkrunarfræðingar. Hjúkrunarfræðingar meta hins vegar samhengi starfs síns marktækt lægra en bæði stjórnendur $(p=0,00)$ og verkfræðingar $(p=0,00)$.

Tafla 5. Samanburður á meðaltölum einstakra pátta starfshönnunar fyrir störfin prjú.

\begin{tabular}{lcccccccccc}
\hline & \multicolumn{2}{c}{ Hjúkrunarfræðingar } & \multicolumn{2}{c}{ Verkfræðingar } & \multicolumn{2}{c}{ Stjórnendur } \\
& $\mathrm{N}$ & Mt. & St.frv. & Mt. & St.frv. & Mt. & St. frv. df & F & $P(\mathrm{~m}$. hópa) \\
\hline Einkenni verkefna & $69-177$ & 3,81 & 0,50 & 3,91 & 0,52 & 4,00 & 0,44 & 2 & 5,40 & 0,007 \\
Einkenni pekkingar & $69-177$ & 4,19 & 0,51 & 3,99 & 0,43 & 4,06 & 0,50 & 2 & 3,69 & 0,026 \\
Félagsleg einkenni & $69-175$ & 3,47 & 0,40 & 3,64 & 0,38 & 3,62 & 0,46 & 2 & 4,13 & 0,017 \\
Samhengi starfsins & $69-176$ & 2,76 & 0,40 & 4,06 & 0,34 & 4,08 & 0,39 & 2 & 3,38 & 0,000 \\
Starfsánægja & $69-177$ & 4,21 & 0,69 & 4,13 & 0,69 & 4,29 & 0,61 & 2 & 1,82 & 0,160 \\
\hline
\end{tabular}

Mt = međaltal St.frv. = stađalfrávik

Eins og sjá má í töflu 6 má merkja marktækan mun á mati sérfræðinga á allflestum einstökum undirpáttum eftir pví hvaða starfi peir gegna. Hvað varðar Einkenni verkefna og sjálfstæði í skipulagi $(p=0,00)$, ákvarðanatöku $(p=0,01)$ og vinnubrögðum $(p=0,01)$ meta stjórnendur pá pætti alla marktækt hærra en hjúkrunarfræðingar. Ekki greinist munur á páttum er lúta að sjálfstæði, milli verkfræðinga og stjórnenda. Hjúkrunarfræðingar meta hins vegar fjölbreytni verkefna $(p=0,00)$ marktækt hærra en verkfræðingar og hjúkrunarfræðingar meta mikilvægi starfs ( $p=0,00$ og $p=0,00)$ síns marktækt meira en bæði verkfræðingar og stjórnendur. Stjórnendur og verkfræðingar meta pó heildstæði verkefna $(p=0,00$ og $p=0,00$ ) marktækt hærra en hjúkrunarfræðingar. Ekki greinist marktækur munur á milli pessara priggja starfsstétta varðandi beina endurgjöf um frammistöðu frá starfinu sjálfu.

Merkja má minni breytileika eftir störfum á undirpáttum Einkenna pekkingar (sjá töflu 5) en á einkennum verkefna, og matið sambærilegt á bæði margbreytileika í starfi og úrlausn vandamála. Á hinn bóginn vegar meta hjúkrunarfræðingar úrvinnslu upplýsinga $(p=0,03)$, sem og fjölbreytileika í færni sem starfið gerir kröfur um $(p=0,00)$, marktækt meiri í sínu starfi en verkfræðingar gera. Einnig meta hjúkrunarfræðingar sérhæfingu sína $(p=0,00$ og $p=0,00$ ) marktækt meiri en bæði verkfræðingar og stjórnendur.

Pegar kemur að Félagslegum einkennum má fyrst og fremst merkja mun í mati á páttunum áhrif á störf annarra og samskiptum við aðila utanhúss (sjá töflu 6). Verkfræðingar meta áhrif af störfum sínum á störf annarra $(p=0,00$ og $p=0,00)$ marktækt hærra en bæði hjúkrunarfræðingar og stjórnendur. Stjórnendur meta hins vegar samskipti sín við aðila utanhúss $(p=0,02)$ marktækt meiri en hjúkrunarfræðingar. Ekki er marktækur munur á mati verkfræðinga og stjórnenda á samskiptum utanhúss. 
Tafla 6. Samanburður á meðaltölum einstakra undirpátta milli starfa.

\begin{tabular}{lcccccccc}
\hline & \multicolumn{3}{c}{ Hjúkrunarfræđingar } & \multicolumn{3}{c}{ Verkfræðingar } & \multicolumn{3}{c}{ Stjórnendur } \\
& N & Mt. & St.frv. & Mt. & St. frv. & Mt. & St. frv. P (m. hópa) \\
\hline Einkenni verkefna & & & & & & & & \\
Sjálfstæđi í skipulagi & $76-183$ & 3,46 & 0,90 & 4,18 & 0,59 & 4,33 & 0,50 & 0,000 \\
Sjálfstæð ákvarđanataka & $76-183$ & 4,06 & 0,70 & 4,16 & 0,68 & 4,32 & 0,63 & 0,010 \\
Sjálfstæð vinnubrögð & $76-183$ & 3,52 & 0,85 & 4,04 & 0,66 & 4,20 & 0,65 & 0,000 \\
Fjölbreytni verkefna & $76-183$ & 4,56 & 0,58 & 4,17 & 0,64 & 4,37 & 0,69 & 0,001 \\
Mikilvægi starfs & $76-183$ & 4,35 & 0,61 & 3,73 & 0,79 & 3,81 & 0,81 & 0,000 \\
Heildstæđi verkefna & $76-183$ & 3,27 & 0,88 & 3,69 & 0,73 & 3,61 & 0,80 & 0,001 \\
Endurgjöf frá starfi & $76-183$ & 3,23 & 0,97 & 3,46 & 0,87 & 3,49 & 0,86 & 0,081 \\
Einkenni pekkingar & & & & & & & & \\
Margbreytileiki starfs & $75-183$ & 4,00 & 0,62 & 4,06 & 0,65 & 4,18 & 0,73 & 0,118 \\
Úrvinnsla upplýsinga & $75-183$ & 4,37 & 0,69 & 4,11 & 0,58 & 4,29 & 0,58 & 0,027 \\
Úrlausn vandamála & $75-183$ & 3,93 & 0,64 & 4,11 & 0,53 & 4,02 & 0,64 & 0,178 \\
Fjölbreytileiki færni & $75-183$ & 4,43 & 0,66 & 4,09 & 0,64 & 4,23 & 0,62 & 0,004 \\
Sérhæfing & $75-183$ & 4,22 & 0,72 & 3,54 & 0,76 & 3,58 & 0,83 & 0,000 \\
Félagsleg einkenni & & & & & & & & \\
Félagslegur stuðningur & $72-174$ & 4,29 & 0,46 & 4,22 & 0,48 & 4,32 & 0,51 & 0,359 \\
Áhrif á störf annarra & $72-174$ & 2,82 & 0,73 & 3,50 & 0,82 & 3,03 & 0,99 & 0,000 \\
Áhrif annarra á mín störf & $72-174$ & 3,59 & 0,93 & 3,81 & 0,76 & 3,57 & 0,88 & 0,146 \\
Samskipti utanhúss & $72-174$ & 3,11 & 0,98 & 3,24 & 1,00 & 3,46 & 0,90 & 0,018 \\
Endurgjöf frá öđrum & $72-174$ & 2,81 & 1,00 & 2,99 & 0,91 & 3,07 & 0,93 & 0,139 \\
Samhengi starfs & & & & & & & & \\
Vinnuvistfræđi & $72-175$ & 2,69 & 0,96 & 4,48 & 0,79 & 4,58 & 0,62 & 0,000 \\
Líkamlegar kröfur & $72-175$ & 2,69 & 0,96 & 4,48 & 0,79 & 4,58 & 0,62 & 0,000 \\
Vinnuađstæđur & $72-175$ & 2,98 & 0,77 & 3,91 & 0,70 & 3,83 & 0,82 & 0,000 \\
Notkun tækja & $72-175$ & 2,32 & 0,90 & 3,40 & 1,09 & 3,55 & 1,11 & 0,000 \\
\hline
\end{tabular}

m. hópa = milli hópa

Að lokum, pá meta hjúkrunarfræðingar alla undirpætti starfshönnunarpáttarins Samhengi starfs, p.e.a.s. vinnuvistfræði, líkamlegar kröfur, vinnuaðstæður og notkun tækja, marktækt verri (lægra) en hvoru tveggja stjórnendur og verkfræðingar ( $p=0,00$ í öllum tilvikum).

\section{Umræða}

Par sem fáar rannsóknir liggja fyrir um hönnun starfa, sér í lagi sérfræðistarfa hér á landi, var markmiðið að greina áhrif einstakra hönnunarpátta og einkenna í sérfræðistörfum á starfsánægju og bera saman hönnun starfa og starfsánægju meðal hjúkrunarfræðinga, verkfræðinga og stjórnenda. Pær niðurstöður sem hér eru kynntar eru hluti af alpjóðlegri rannsókn (Global Work Design) par sem pátttakendur voru frá 40 löndum. Gagna var aflað með samræmdum hætti í öllum pátttökulöndunum en hér er aðeins greint frá niðurstöðum fyrir Ísland. Pátttakendur voru hjúkrunarfræðingar, verkfræðingar, og stjórnendur og mælitækið samanstóð af spurningalista um starfshönnun WDQ (Morgenson \& Humphrey, 2006) og spurningum um almenna starfsánægju (Campion, 1988).

Niðurstöður sýna fram á tengsl allra fjögurra yfirpátta starfshönnunar, eða einkenna starfanna, og starfsánægju og skýra alls 21 undirpættir starfshönnunar saman $35 \%$ af dreifni í starfsánægju, en skýra 25\% af dreifni pegar greint með yfirpáttum. Áhrif yfirpáttanna einkenni pekkingar og samhengis eru pó ekki marktæk í fjölbreytuaðhvarfsgreiningu. Pessar niðurstöður eru í samræmi við kenningu Herzberg (1968) um að innri hvatar skapi starfsánægju, og við kenningu Karasek $(1979 ; 1982)$ um hvernig sjálfstæði í starfi og stuðningur séu mikilvægir til að vega upp á móti auknu álagi og kröfum í starfi (og gera má ráð fyrir að sé raunin í sérfræðistörfum). Tengslin eru sterkust milli 
einkenna verkefna, p.e.a.s. sjálfstæði, fjölbreytni verkefna, mikilvægi starfs og heildstæði verkefna og starfsánægju. Undirpættirnir fjölbreytni verkefna, endurgjöf frá öðrum, sjálfstæð ákvarðanataka, vinnuaðstæður, og mikilvægi starfs hafa par mest áhrif. Prír pessara fimm pátta, fjölbreytni verkefna, sjálfstæð ákvarðanataka og mikilvægi starfs, skilgreinast sem Einkenni verkefna. Pessar niðurstöður eru pví í samræmi við ýmsar kenningar og fyrri rannsóknir sem gefa til kynna að starfið sjálft, verkefnin og stuðningur í formi endurgjafar hafi áhrif á starfsánægju og hvatningu í starfi. Má par nefna nýlega rannsókn Han, Carter og Champion (2018) par sem getan til að taka ákvarðanir, og félagslegur stuðningur höfðu jákvæð tengsl við starfsánægju. Einnig eru pessar niðurstöður í ágætu samræmi við safngreiningu Humphrey og félaga (2007) og við fyrri rannsóknir hér á landi (Arney Einarsdóttir, 2007; Gunnarsdóttir, 2005).

Starfsánægja meðal peirra priggja hópa sem hér voru skoðaðir, hjúkrunarfræðinga, verkfræðinga og stjórnenda, var nokkuð há og sambærileg hjá öllum premur hópunum. Ekki greindust marktæk tengsl, hvorki með einfaldri tengslagreiningu né með fjölbreytuaðhvarfsgreiningu, á milli aldurs, kyns, menntunar og lengdar vinnuviku við starfsánægju, prátt fyrir að pessir pættir skýri saman 3,5\% af dreifni í starfsánægju. Petta er í samræmi við fyrri rannsóknir hér á landi að pessir pættir hafi ekki einir og sér áhrif á starfsánægju (Arney Einarsdóttir \& Sigríður P. Stefánsdóttir, 2008). Pessar niðurstöður endurspegla pó að öllum líkindum annað eða hvoru tveggja, menningarlegan mun eða аð аðrir pættir eigi við um sérfræðistörf en störf ófaglærðra par sem eldri erlendar rannsóknir hafa sýnt fram á að konur séu ánægðari en karlar og að neikvæð tengsl séu milli menntunar og starfsánægju og U-laga tengsl aldurs (Clark, 1997; Clark, Oswald, \& Warr, 1996; Sousa-Poza \& Sousa-Poza, 2000). Pessar niðurstöður benda pví til pess að pessir lýðfræðilegu pættir hafi ekki áhrif á starfsánægju í sérfræðistörfum hér á landi. Pess má pó geta í pessu samhengi að karlar meta félagsleg einkenni sinna starfa betri en konur og vinnuvikan er lengri hjá peim en konum.

Marktækur munur greinist á starfshönnunarpáttunum fjórum, p.e. að munur var á mati stjórnenda og hjúkrunarfræðinga á einkennum verkefna (sjálfstæði í skipulagi, ákvarðanatöku og vinnubrögðum, fjölbreytni verkefna, mikilvægi starfs og heildstæði verkefna ásamt endurgjöf frá starfi) og meta stjórnendur pau hærri en hjúkrunarfræðingar. Hjúkrunarfræðingar meta á hinn bóginn einkenni pekkingar hærra en stjórnendur og má rekja pað m.a. til hás mats á fjölbreytileika færni sem starfið krefst. Verkfræðingar og stjórnendur meta jafnframt félagsleg einkenni (félagslegur stuðningur, áhrif á störf annarra og áhrif á mín störf, samskipti utanhúss og endurgjöf frá öðrum) starfs síns sem betri en hjúkrunarfræðingar. Hjúkrunarfræðingar meta hins vegar alla pætti sem falla undir samhengi starfs (vinnuvistfræði, líkamlegar kröfur, vinnuaðstæður og notkun tækja) verri í sínum störfum en bæði stjórnendur og verkfræðingar. Hugsanlegar skýringar geta falist í pví að hjúkrunarfræðingar sem tóku pátt í rannsókninni starfa á opinberum heilbrigðisstofnunum en vísbendingar eru um að par hafi álag aukist undanfarin ár (Ríkisendurskoðun, 2017). Раð bendir til pess að horfa purfi til vinnuaðstæðna, áhrifa á eigin störf og stuðnings í starfi hjá hjúkrunarfræðingum og að par sé svigrúm til að bæta um betur.

Enginn peirra pátta sem hér eru skilgreindir sem einkenni pekkingar (margbreytileiki starfs, úrvinnsla upplýsinga, úrvinnsla vandamála, fjölbreytileiki færni og sérhæfing) hefur skýrandi áhrif á starfsánægju. Рað má pó hugsanlega skýra með pví að ekki er um að ræða mikinn breytileika hvað varðar kröfur eða pörf á pekkingu í peim störfum sem hér um ræðir, p.e.a.s. meðal hjúkrunarfræðinga, verkfræðinga og stjórnenda. Að auki eru allflestir, eða yfir 90\% svarenda með háskólamenntun. Hér er pví hópurinn sérfræðimenntaður og margbreytileiki starfsins, úrvinnsla upplýsinga, úrlausn vandamála, fjölbreytileiki færni og sérhæfing ekki pað sem sker úr um hvort viðkomandi starfsmenn séu ánægðir í starfi sínu með sama hætti og ef um fjölbreyttari hóp og störf væri að ræða.

Munur var á mati pessara priggja sérfræðihópa eftir störfum peirra á allflestum einstökum undirpáttum. Pá má nefna einkenni verkefna og sjálfstæði í skipulagi og ákvarðanatöku 
ásamt vinnubrögðum en stjórnendur meta alla pá pætti marktækt hærra en hjúkrunarfræðingar. Ekki greinist pó munur á páttum er varða sjálfstæði, milli verkfræðinga og stjórnenda. Hjúkrunarfræðingar meta fjölbreytni verkefna sinna meira en verkfræðingar og meta mikilvægi starfs síns meira en bæði verkfræðingar og stjórnendur. Stjórnendur og verkfræðingar meta heildstæði verkefna betra en hjúkrunarfræðingar sem bendir til pess að peir upplifi í ríkari mæli að peir klári verkefnin sín, eða að peir fái frekar að upplifa hluti verða að veruleika. Pennan breytileika má eflaust að einhverju leyti rekja til einkenna starfanna og til álags sem m.a. eykur hættu á að hjúkrunarfræðingar geti ekki lokið verki í samræmi við faglegar kröfur (Gunnarsdóttir, 2005, bls. 155-160).

Merkja má lítinn breytileika eftir störfum á einstökum páttum sem skilgreinast sem einkenni pekkingar. Pegar kemur að félagslegum einkennum má fyrst og fremst merkja mun í mati á páttunum áhrif á störf annarra og samskiptum við aðila utanhúss en stjórnendur meta samskipti sín utanhúss meiri en hjúkrunarfræðingar og endurspeglar pað eflaust eðli starfanna. Niðurstöður hér sýna að endurgjöf frá öðrum sem skilgreinist sem félagslegt einkenni, hafi áhrif á starfsánægju og er mat pessara priggja sérfræðihópa tiltölulega lágt á peim pætti. Pví má ætla að svigrúm sé til að bæta um betur á pessu sviði fyrir alla hópana prjá. Aukin áhersla á frammistöðumat og starfsmannasamtöl, auk daglegs samráðs og samtals, gætu verið árangursríkar leiðir til að veita formlega og reglubundna endurgjöf og stuðning til pessara sérfræðinga, til að viðhalda ánægju peirra í starfi. Hjúkrunarfræðingar meta alla undirpætti starfshönnunarpáttarins samhengi starfs lægra en bæði stjórnendur og verkfræðingar. Í ljósi niðurstaðna hér um áhrif vinnuaðstæðna á starfsánægju má ætla að pörf sé á að huga að pví hvernig megi bæta um betur á pessu sviði fyrir hjúkrunarfræðinga. Par sem fjölbreytni verkefna og mikilvægi starfs hjúkrunarfræðinga fá hátt mat hér, gætu peir pættir verið að vega upp á móti peirri upplifun að skortur sé á sjálfstæði. Pá gætu peir einnig vegið upp slæmar vinnuaðstæður og er pað í takt við niðurstöður fyrri rannsókna hér á landi (Gunnarsdóttir, 2006 og Halldórsdóttir o.fl., 2018). Рað vekur einnig athygli, í ljósi pess að upplifun á mikilvægi starfs skiptir máli, að stjórnendur og verkfræðingar meta pann pátt mun lægra en hjúkrunarfræðingar. Vert er að hafa í huga í pessu samhengi að allir pessir pættir hafa samkvæmt peim niðurstöðum sem hér eru birtar áhrif á starfsánægju pessara sérfræðinga.

Að lokum er mikilvægt að hafa í huga takmarkanir rannsóknarinnar og að hér er um að ræða prjú ólík sérfræðistörf hjúkrunarfræðinga, verkfræðinga og stjórnenda. Niðurstöður gefa pví fyrst og fremst vísbendingar um hönnun starfa hjá pessum premur starfsstéttum. Einnig er um að ræða niðurstöður pversniðsrannsóknar og er ekki hægt að alhæfa niðurstöður yfir á önnur störf. Pví væri verðugt framtíðarverkefni að rannsaka fleiri sérfræðistörf, til að mynda störf kennara, viðskiptafræðinga, lögfræðinga o.s.frv. Úrtakið var tekið úr nokkrum völdum fyrirtækjum og stofnunum, nema fyrir stjórnendur par sem pað var tekið úr félagatali félagasamtaka sem stjórnendur eiga aðild að. Рað nær pví til mun fleiri fyrirtækja. Pví er hugsanlegt að niðurstöður fyrir hjúkrunarfræðinga og verkfræðinga endurspegli fyrst og fremst hönnun starfa á viðkomandi vinnustöðum frekar en fyrir alla í viðkomandi starfsgrein.

Pátttakendur í stjórnendaúrtaki voru ekki spurðir sérstaklega hvort peir væru í stjórnendastarfi. Par sem úrtakið var tekið úr félagatali fagfélags stjórnenda og skýrt var tekið fram í inngangi könnunar að verið væri að rannsaka störf stjórnenda má pó gera ráð fyrir að hvati til pátttöku hafi verið meiri meðal stjórnenda en annarra félagsmanna. Auk pess má geta pess að ekki eru allir í svarendahópi stjórnenda með mannaforráð en ætla má að viðkomandi svarendur beri pá fyrst og fremst ábyrgð á verkefnum og fjármunum, líkt og getur verið raunin með verkefnisstjóra, gæðastjóra og mannauðsstjóra í minni fyrirtækjum, svo örfá dæmi séu tekin. Pau störf má pví skilgreina sem sérfræðistörf með stjórnendaábyrgð.

Eins og áður hefur komið fram pá er lítið sem ekkert til um samanburðarrannsóknir á 
hönnun sérfræðistarfa hér á landi sem og erlendis. Pó allnokkrar rannsóknir séu til á störfum hjúkrunarfræðinga er fræðileg pekking á störfum verkfræðinga og stjórnenda nokkuð takmörkuð. Að auki hafa störf hjúkrunarfræðinga gjarnan verið skoðuð án samanburðar við önnur störf og hér er pví tækifæri til að bera pessi störf saman. Pessari rannsókn er pví ætlað аð bæta um betur með tilliti til pessa.

\section{Lokaord}

Rannsóknin varpar ljósi á að starfið sjálft, p.e.a.s. verkefnin, sjálfstæði og mikilvægi peirra ásamt stuðningi í formi endurgjafar og að vinnuaðstæður séu meðal mikilvægra pátta starfshönnunar fyrir starfsánægju sérfræðinga hér á landi. Í pessari rannsókn var um að ræða samanburð milli priggja hópa sérfræðinga og hefur samkvæmt bestu vitneskju rannsakenda slík rannsókn ekki verið framkvæmd áður hér á landi. Niðurstöður rannsóknarinnar eru pví framlag til próunar pekkingar á sviði starfshönnunar og á störfum pessara sérfræðinga og geta pær nýst sérfræðingum og stjórnendum við frekari próun pessara starfa. Mikilvægt er að halda áfram að próa pekkingu á pessu sviði hér á landi og sér í lagi að huga nánar að rannsóknum á störfum verkfræðinga og stjórnenda par sem lítið er til af rannsóknum á peirra störfum. Рað virðist pví tímabært á tímum mikilla breytinga og hraðrar tæknipróunar að fylgjast með hönnun starfa í ólíkum sérfræðigreinum. Einnig er verðugt að fylgjast með pví hvort, og pá hvernig, pessi sömu störf muni taka breytingum og hvaða áhrif pað muni hafa á ýmis vinnutengd viðhorf peirra sem störfunum gegna.

\section{Heimildir}

Arney Einarsdóttir. (2007). Áhrifavaldar starfsánægju og hvatningar. Íslensk stöðlun og prófun á Evrópsku starfsánægjuvísitölunni. í Rannsóknir í félagsvísindum (Vol. VIII, pp. 39-50). Reykjavík: Félagsvísindastofnun.

Arney Einarsdóttir, \& Sigríður P. Stefánsdóttir (2008). Lýðfræðilegir áhrifavaldar starfsánægju á Íslandi. Ingjaldur Hannibalsson (ritstjóri). Í Rannsóknir i félagsvísindum VIII (pp. 39-50). Reykjavík: Félagsvísindastofnun Háskóla Íslands.

Arney Einarsdóttir \& Ásta Bjarnadóttir. (2010). Tveir vinnumarkaðir og hrun: Áhrif á upplifun og hegðun starfsmanna. Tímarit um viðskipti og efnahagsmál, 7(1), 1-20.

Boselie, P., Dietz, G., \& Boon, C. (2005). Commonalities and contradictions in HRM and performance research. Human Resource Management Journal, 15(3), 67-94.

Campion, M. A. (1988). Interdisciplinary approaches to job design: A constructive replication with extensions. Journal of Applied Psychology, 73(3), 467-481.

Campion, M. A., \& Thayer, P. W. (1985). Development and field evaluation of an interdisciplinary measure of job design. Journal of Applied Psychology, 70(1), 29-43.

Cantarelli, P., Belardinelli, P., \& Belle, N. (2016). A meta-analysis of job satisfaction correlates in the public administration literature. Review of Public Personnel Administration, 36(2), 115-144.

Carleton, K. (2011). How to motivate and retain knowledge workers in organizations: A review of the literature. International Journal of Management, 28(2), 459-468.

Clark, A. E. (1997). Job satisfaction and gender: why are women so happy at work? Labour Economics, 4(4), 341-372.

Clark, A., Oswald, A., \& Warr, P. (1996). Is job satisfaction U-shaped in age? Journal of Occupational and Organizational Psychology, 69(1), 57-81.

Drucker, P. F. (1999). Knowledge-worker productivity: The biggest challenge. California Management Review, 41(2), 79-94.

Fahr, R. (2011). Job Design and Job Satisfaction-Empirical Evidence for Germany? Management Revue, 22(1), $28-46$.

Félag Íslenskra hjúkrunarfræðinga. (2019). Ársskýrsla 2018-2019. Sótt af https://www.hjukrun.is/library/SkrarNeW/utgefid-efni/Skyrslur/HJUKRUN_ARSSKYRSLA_2018_vefur.pdf

Guðjón Ingi Guðjónsson og Sigrún Gunnarsdóttir. (2014). Pjónandi forysta og starfsánægja í Háskóla Íslands. Stjórnmál og Stjórnsýsla, 10(2), 499-522.

Guðmundur Ingi Guðmundsson og Guðbjörg Linda Rafnsdóttir. (2010). Starfsánægja framhaldsskólakennara: Innri og ytri áhrifapættir. Uppeldi og menntun, 19(1-2), 113-127.

Gunnarsdóttir, S. (2005). Quality of working life and quality of care in Icelandic hospital nursing (doktorsritgerð). London, UK: London School of Hygiene \& Tropical Medicine. 
Gunnarsdóttir, S., Clarke, S. P., Rafferty, A. M., \& Nutbeam, D. (2009). Front-line management, staffing and nurse-doctor relationships as predictors of nurse and patient outcomes. A survey of Icelandic hospital nurses. International Journal of Nursing Studies, 46(7), 920-927.

Hackman, J. R., \& Oldham, G. R. (1975). Development of the job diagnostic survey. Journal of Applied Psychology, 60(2), 159-170.

Hagstofa Íslands. (2018a). Sótt 27. maí 2019 af https:/px.hagstofa.is/pxis/pxweb/is/Atvinnuvegir/Atvinnuvegir_fyrirtaeki_fjoldi_stjornir/FYR06101.px

Hagstofa Íslands. (2018b). Sótt 15. mars 2019 af https://hagstofa.is/talnaefni/samfelag/vinnumarkadur/vinnumarkadsrannsokn/

Halldórsdóttir, S., Einarsdóttir, E. J., \& Eðvarðsson, I. R. (2018). Effects of cutbacks on motivating factors among nurses in primary health care. Scandinavian Journal of Caring Sciences, 32(1), 397-406.

Han, R. M., Carter, P., \& Champion, J. D. (2018). Relationships among factors affecting advanced practice registered nurses' job satisfaction and intent to leave: A systematic review. Journal of the American Association of Nurse Practitioners, 30(2), 101-113.

Hlín Kristbergsdóttir, Leifur Geir Hafsteinsson og Arney Einarsdóttir (2008). Samanburður á upplifun starfsmanna einkarekinna fyrirtækja og starfsmanna hins opinbera af vinnustað og starfi. Sálfræðitímaritið Tímarit Sálfræđingafélags Íslands, 13, 127-146.

Herzberg, F. (1968). One more time: How do you motivate employees. Harvard Business Review, 81(1), 87-96.

Hjördís Sigursteinsdóttir. (2016). "Vinnugleðin hefur tapast, nú er bara álag og erfitt og lítil gleði": Starfsumhverfi opinberra starfsmanna á tímum efnahagsprenginga. Stjórnmál og stjórnsýsla, 12(2), 417-442.

Hulda Rafnsdóttir, Ragnheiður Harpa Arnarsdóttir, \& Sigrún Gunnarsdóttir (2015). Árangur og forysta í hjúkrun: viðhorf til pjónandi forystu, starfsánægju, starfstengdra pátta og gæða pjónustu á Sjúkrahúsinu á Akureyri. Tímarit Hjúkrunarfræðinga, 91(4), 8-16.

Humphrey, S. E., Nahrgang, J. D., \& Morgeson, F. P. (2007). Integrating motivational, social, and contextual work design features: a meta-analytic summary and theoretical extension of the work design literature. Journal of Applied Psychology, 92(5), 1332-1356.

International Labour organization. (2016). Workplace stress: A collective challenge. Geneve: International Labour Organization.

Karasek, R. A. (1979). Job demands, job decision latitude and mental strain: implications for job redesign. Aministrative Science Quarterly, 24(2), 285-306.

Karasek, R. A., Trinatis, K. P., \& Chaudry, S. S. (1982). Coworker and supervisor support as moderators of associations between task characteristics and mental strain. Journal of Occupational Behavior, 3(2), 181-200.

Kinman, G. (2016). Effort-reward imbalance and overcommitment in UK academics: implications for mental health, satisfaction and retention. Journal of Higher Education Policy and Management, 38(5), 504-518.

Li, H., Shi, Y., Li, Y., Xing, Z., Wang, S., Ying, J., Zhang, M., Sun, J. (2018). Relationship between nurse psychological empowerment and job satisfaction: A systematic review and meta-analysis. Journal of Advanced Nursing, 74(6), 1264-1277.

Lorente, L., Tordera, N., \& Peiró, J. (2018). How work characteristics are related to european workers' psychological well-being. A comparison of two age groups. International Journal of Environmental Research and Public Health, 15(1), 127-138.

Marmot, M. G., Smith, G. D., Stansfeld, S., Patel, C., North, F., Head, J., White, I., Brunner, E., Feeney, A. (1991). Health inequalities among British civil servants: the Whitehall II study. The Lancet, 337(8754), 1387-1393.

Morgeson, F. P., \& Humphrey, S. E. (2006). The Work Design Questionnaire (WDQ): developing and validating a comprehensive measure for assessing job design and the nature of work. Journal of Applied Psychology, 91(6), 1321-1339.

Morgeson, F. P., \& Humphrey, S. E. (2008). Job and team design: Toward a more integrative conceptualization of work design. In Research in personnel and human resources management (pp. 39-91). Emerald Group Publishing Limited.

OECD. (n.d.). Average usual weekly hours worked on the main job. Retrieved December 28, 2016, from https:// stats.oecd.org/Index.aspx?DataSetCode=AVE_HRS

Ómar H. Kristmundsson. (2007). Könnun á starfsumhverfi ríkisstarfsmanna 2006 - Niðurstöður. Reykjavík: Fjármálaráðuneytið.

Pellerin, S., \& Cloutier, J. (2018). The effects of rewards on psychological health in the workplace: Underlying mechanisms. Canadian Journal of Administrative Sciences/Revue Canadienne Des Sciences de l'Administration, 35(3), 361-372.

Ríkisendurskoðun. (2017). Hjúkrunarfræðingar: Mönnun, menntun og starfsumhverfi. Reykjavík: Ríkisendurskoðun.

Seibert, S. E., Wang, G., \& Courtright, S. H. (2011). Antecedents and consequences of psychological and team empowerment in organizations: A meta-analytic review. Journal of Applied Psychology, 96(5), 981-1003.

Siegerist, J. (1996). Adverse Health Effects of High Effort/Low-Reward Jobs. International Journal of Health Services, 26, 569-589.

Sigrún Gunnarsdóttir og Sandra Borg Gunnarsdóttir. (2018). Pjónandi forysta og starfsánægja í framhaldsskólum. Netla - Veftímarit um uppeldi otg menntun: Sérrit 2018 - Menntavika 2018, 1-19. 
Sousa-Poza, A., \& Sousa-Poza, A. A. (2000). Well-being at work: a cross-national analysis of the levels and determinants of job satisfaction. The Journal of Socio-Economics, 29(6), 517-538.

Stansfeld, S. A., Fuhrer, R., Shipley, M. J., \& Marmot, M. G. (1999). Work characteristics predict psychiatric disorder: prospective results from the Whitehall II Study. Occupational and Environmental Medicine, 56(5), 302-307.

Taylor, F. W. (1911). The principles of scientific management. New York, NY: Harper \& Brothers.

Verkfræðingafélag Íslands. (2019). Ársskýrsla starfsárið 2018-2019. Sótt af https://www.vfi.is/media/utgafa/ VFI_arsskyrsla_2019_profork_WEB.pdf 


\section{Viðauki I. Fylgnigreining undirpátta WDQ}

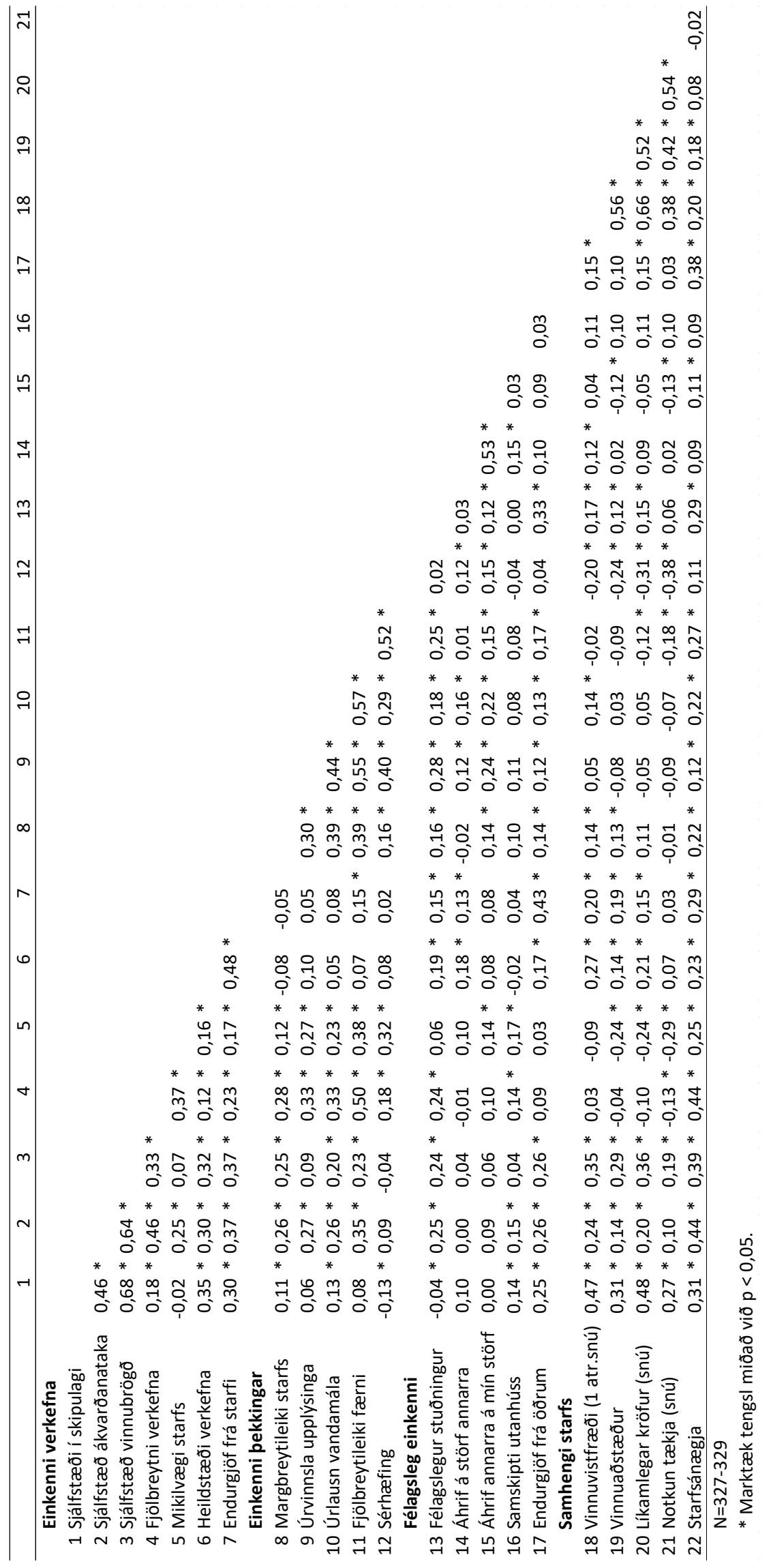

